\section{Potential for saturated riparian buffers to treat tile drainage among 32 watersheds representing lowa landscapes}

\author{
M.D. Tomer, S.A. Porter, D.E. James, and J.D. Van Horn
}

\begin{abstract}
The saturated riparian buffer $(\mathrm{SRB})$ is a new and cost-effective conservation practice that diverts agricultural tile drainage toward subsurface discharge within riparian buffers to achieve nitrate $\left(\mathrm{NO}_{3}-\mathrm{N}\right)$ removal. Conservation planners want to understand the potential role of the SRB practice for reducing $\mathrm{NO}_{3}-\mathrm{N}$ loads from tile-drained agricultural watersheds The Agricultural Conservation Planning Framework (ACPF) includes a tool for identifying riparian zones where the SRB practice can be installed with minimal risks of unintended consequences (i.e., crop inundation and streambank failure). Watershed assessment of the potential role for SRBs, however, must identify where SRB-suited sites can actually receive drainage from tile-drained fields. This study compared the extent of SRB-suited riparian sites among 32 Iowa watersheds, and estimated the proportion of each watershed that was tile drained and located above SRB-suited riparian zones. Results showed the extent of sites suited for SRBs did not significantly differ among three Major Land Resource Areas (MLRAs) in Iowa, from which the selected watersheds were randomly chosen. Most watersheds had suitable sites along $30 \%$ to $70 \%$ of streambank lengths, where tile drainage from $15 \%$ to $40 \%$ of the watershed areas could be diverted, based on estimated extents of tile drainage above suitable sites. Therefore, the SRB has an important potential role for water quality improvement in many tile-drained watersheds in Iowa. However, the SRB practice is not readily designed for treating drainage from headwater catchments, which frequently comprised more than $30 \%$ of watershed areas in headwater streams of north central Iowa (MLRA 103), where tile drainage is extensive.
\end{abstract}

Key words: Agricultural Conservation Planning Framework-saturated buffers-tile drainage-watershed analysis

Hydrologic modification, including dams, stream straightening, and artificial drainage, has impacted the hydrology and water quality of many watersheds (Carlisle et al. 2010; Simon and Rinaldi 2006). In the US Midwest, artificial (tile) drainage has enabled agricultural production, yet carries a substantial portion of the nitrate $\left(\mathrm{NO}_{3}-\mathrm{N}\right)$ loads found in the upper Mississippi River and its tributaries (Amado et al. 2017). Several practices can be placed to intercept tile drainage and reduce $\mathrm{NO}_{3}-\mathrm{N}$ loads via denitrification, including nutrient removal wetlands (Hefting et al. 2013) and woodchip bioreactors (Schipper et al. 2010).

Woodchip bioreactors are an edge-of-field practice and are typically installed to treat $<40$ ha of drainage. Performance of woodchip bioreactors for $\mathrm{NO}_{3}-\mathrm{N}$ removal is affected by temperature and hydraulic residence time (Hoover et al. 2015). Watershed-wide installation of bioreactors could potentially reduce $\mathrm{NO}_{3}-\mathrm{N}$ loads in streams by $20 \%$ to 30\% (Moorman et al. 2015), but excavation and woodchip transportation costs must be considered (Christianson et al. 2013). Nitrate removal rates in wetlands receiving tile drainage often exceed 45\% (Kovacic et al. 2000; Lenhart et al. 2016; Groh et al. 2015); a properly sized wetland can treat drainage from

Received July 18, 2019; Revised September 20, 2019; Accepted November 15, 2019; Published online April 25, 2020. large areas (i.e., hundreds of hectares), but land acquisition comprises a major cost for wetland installation (Christianson et al. 2013).

Riparian soils can also reduce $\mathrm{NO}_{3}-\mathrm{N}$ in subsurface waters (Mayer et al. 2007), but tile drainage discharge typically bypasses riparian zones via subsurface pipes. However, the saturated riparian buffer (SRB) is a new conservation practice, recently approved for USDA cost sharing, which diverts tile drainage to be treated through riparian-soil processes (Jaynes and Isenhart 2014, 2019). A gated water level control box, installed along the tile line within the riparian buffer, is used to divert a portion of the tile flow along lateral distribution lines laid parallel to and 10 to $15 \mathrm{~m}$ from the stream. The control box raises the water table to within about $30 \mathrm{~cm}$ of the surface, causing the diverted tile flow to interact with carbon (C)-rich A horizon soil (topsoil), where denitrification can occur. When tile discharge rates exceed the hydraulic capacity of riparian soils to accept drainage water, discharge can pass through the control box to the original tile outfall along the ditch/stream (Jaynes and Isenhart 2014). This practice involves small land acquisition and installation costs, compared to wetland and bioreactor practices, and hence are a viable and cost-effective option for tile drainage treatment (Jaynes and Isenhart 2019). However, not all riparian sites are suited to $\mathrm{SRB}$ installation. Optimal $\mathrm{NO}_{3}-\mathrm{N}$ removal performance should occur where soil characteristics encourage discharged tile water to flow through riparian soils at shallow depth, where soil organic carbon (SOC) is most readily available to enhance denitrification. It is also important to reduce risks of unintended consequences; particularly inun-

Mark D. Tomer (corresponding author) is a research soil scientist for USDA Agricultural Research Service (ARS), National Laboratory for Agriculture and the Environment, Ames, lowa. Sarah A. Porter is formerly a physical science technician with USDA ARS, National Laboratory for Agriculture and the Environment, currently a senior geographic information systems (GIS) analyst with Environmental Working Group, Minneapolis, Minnesota. David. E. James is a geographic information specialist for USDA ARS, National Laboratory for Agriculture and the Environment, Ames, lowa. Jessica D. Van Horn (Beasley) is formerly a physical science technician with USDA ARS, currently senior GIS analyst, Geographic Technologies Group, Goldsboro, North Carolina. 
dation of cropland adjacent to the SRB, and slumping of saturated stream/ditch banks. The Agricultural Conservation Planning Framework (ACPF; Tomer et al. 2013b; Porter et al. 2018) ArcGIS toolbox includes an SRB siting tool to identify riparian zones where an SRB can be installed with minimal risk of unintended consequences, by avoiding high streambanks potentially subject to bank failure, and flat fields where the practice could inundate adjacent crops (Porter et al. 2018).

In the context of the US Midwest and efforts to reduce $\mathrm{NO}_{3}-\mathrm{N}$ loads, data are needed to characterize how sites suited to the SRB practice are distributed relative to the extent of tile drainage in watersheds. The objective of this paper is to determine whether there is an association between extents of tile-drained agricultural land and of riparian sites suited to SRBs among 32 watersheds that represent Iowa landscape regions with varying extents of tile drainage.

\section{Materials and Methods}

Watershed Selection and Discretization. Thirty-two hydrologic unit code (HUC)12 headwater watersheds were randomly selected for analysis, as described and listed by Tomer et al. (2020b) (figure 1). Watersheds were selected to represent three Major Land Resource Areas (MLRAs; Norton 1937; Olmernik and Griffith 2014; USDA NRCS 2006) and four Agro-Hydrologic Landscape classes (AHLs; Schilling et al. 2015). The MLRAs cover about two-thirds of Iowa (figure 1); MLRA 103 is an area of recent glaciation that has limited stream development and extensive cover of agricultural row crops that are artificially drained; MLRA 104 exhibits somewhat older glacial landscapes with greater stream development with similar wide extent of crop cover; and MLRA $108 \mathrm{C}$ is an older, more incised landscape with a greater mix of crop, pasture, and hardwood forest land cover. The AHL designations summarize soil drainage and slope classes of dominant soil map units of each watershed, abbreviated as either poorly drained (PD) or well drained (WD), followed by a range of slopes, in percentage (i.e., $\mathrm{PD}$ $<2, \mathrm{PD} 2-5, \mathrm{PD}>5$, $\mathrm{WD}<5$, and $\mathrm{WD}>5$ ). These five AHL classes were designated by Schilling et al. (2015) and are meant to link landscape hydrology to conservation practice options for regional and watershed planning. The selected 32 watersheds included four watersheds from each of eight combined classes of MLRA and AHL designations (figure 1; Tomer et al. 2020b).

The ACPF input databases (Tomer et al. 2017) and $2 \mathrm{~m}$ grid digital elevation models (DEMs) were obtained for these 32 watersheds, derived from Light Detection and Ranging (LiDAR) surveys of Iowa (University of Northern Iowa 2016). The DEMs were processed (hydro-modified) to correct overland flow paths where bridges, roads, etc., created "false impoundments" in the DEM (Tomer et al. 2013a), using ACPF tools described by Porter et al. (2018). This process enables the user to make edits (usually cuts through false impoundments) to the DEM, review effects of the edits in correcting flow paths, then adjust the edits in an iterative approach. These edits were made along flow paths with a minimum threshold of 2 ha contributing area. Perennial streams were then designated from among these flow paths by interpreting aerial photography and shaded-relief imagery for each watershed. Land use and soils data were assembled (Tomer et al. 2017) with the edited DEM and stream designation data to complete an ACPF input database for each watershed. The extent of tile drainage in each watershed was estimated as all agricultural fields that were dominated $(>90 \%)$ by low $(<5 \%)$ slopes, and/or were substantially covered (>40\%) by dual soil hydrologic groups, e.g., B/D (Porter et al. 2018).

Land areas contributing to riparian zones along perennial stream reaches in each watershed were discretized into riparian catchments using a $250 \mathrm{~m}$ riparian segment length. In this process, perennial stream reaches are defined from stream initiation points to upper stream confluences, and then successively between stream confluences down to the watershed outlet. Each reach is then divided into that number of equal-length sections of channel that is as close as possible to the selected $(250 \mathrm{~m})$ segment length (Porter et al. 2018). There is an adjustment of these sections within each reach to reduce differences in their straightline lengths, which lengthens the segments where the channel is sinuous and shortens segments that are straight. This step avoids biasing toward delineation of small riparian catchments above sinuous stream lengths. Contributing areas are then defined along each riparian length and split by the channel itself to be delineated as riparian catchments. Headwater catchments that contribute to stream initiation points are also delineated. Porter et al. (2018) and Tomer et al. (2020a) provide further details.

Determining Suitability for Saturated Riparian Buffers. The ACPF riparian practice tools include an SRB placement tool, which was applied to the 32 selected watersheds and their riparian catchments. In developing the SRB tool, there were considerations to identify locations where an SRB should function effectively to reduce $\mathrm{NO}_{3}-\mathrm{N}$ from tile drainage discharged into riparian soils, while avoiding sites with potential for unintended consequences of bank failure (due to saturation of high banks) and/or inundation of adjacent crops (Porter et al. 2018). Briefly, $\mathrm{NO}_{3}-\mathrm{N}$ reduction in riparian soils requires SOC to facilitate denitrification and soil texture and seasonal water table conditions that should encourage shallow, lateral flows toward the stream through saturated riparian soils. The ACPF database includes soils data with derived soil survey information (Tomer et al. 2017) to test whether these soil conditions are likely present in the near-stream environment. To ensure a sufficient $\mathrm{C}$ source, the concentration of SOC between 0 and $100 \mathrm{~cm}$ depth should average 1.0\% (equivalent to $1.7 \%$ soil organic matter). To identify riparian sites where discharged tile water should remain at a shallow soil depth, the seasonal water table depth must be less than $1 \mathrm{~m}$, and the sand plus gravel content at 50 to $150 \mathrm{~cm}$ cannot exceed 65\% in any horizon.

In addition to these soils criteria, topographic criteria were used to check that (1) bank heights were $<3.7 \mathrm{~m}$ (default) to reduce the risk of stream bank collapse, and (2) "moderate" slopes of $2 \%$ to $8 \%$ were extensive across the riparian zone ( $>35 \%$ as default). A slope range of $2 \%$ to $8 \%$ is preferred because if riparian slopes are $<2 \%$, an SRB could raise the chance of crop inundation above the buffer, and where those slopes are $>8 \%$, there may be a risk of return flows (seepage) across the surface, potentially causing soil erosion within the buffer. In a review of buffer literature, Liu et al. (2008) noted that where riparian soils have $>10 \%$ slope, buffer design should consider risks of soil erosion within the buffer. The ACPF criteria limiting extent of soils with $>8 \%$ as an SRB placement criteria recognizes this, but also provides a safety margin considering the enhanced erosion risk involved with controlling for a shallow water table on sloping soils. 


\section{Figure 1}

Map figure showing three Major Land Resource Areas (MLRAs) and the Agro-Hydrologic Landscape (AHL) designations of HUC12 watersheds found within those MLRAs. Locations of $\mathbf{3 2}$ watersheds selected for this study are also shown.

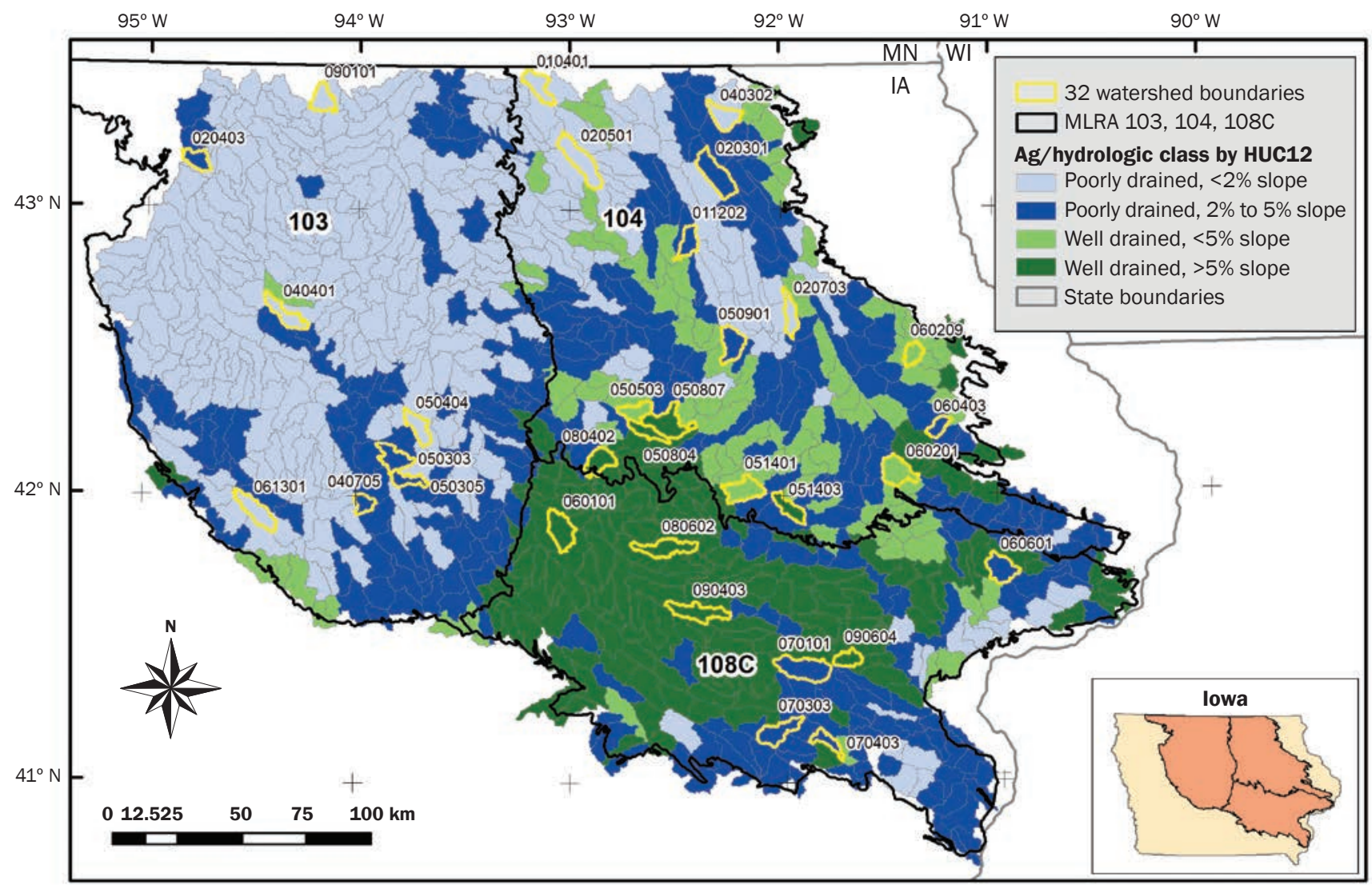

The SRB tool results identify riparian lengths where all these criteria are met, and for those that do not, the reason/s for failure. This emphasizes that ACPF results should be viewed flexibly, and that criteria most limiting for the placement of SRBs will vary among watersheds. The $\mathrm{C}$ requirement is an important case in point because there is evidence that riparian buffer vegetation, through rooting activity, can enhance the free $\mathrm{C}$ available to drive denitrification (Dosskey et al. 2010; Jaynes and Isenhart 2019). To allow the SRB practice to be proposed in watersheds where high $\mathrm{C}$ soils are not common, sites that only fail the SOC criteria are deemed "suitable with C enhancement" because SOC could be augmented through rooting activity of buffer vegetation, or even by direct addition of $\mathrm{C}$, e.g., using denitrification walls (Schipper et al. 2010). Herein, we report riparian sites that are suited for SRBs with those that are suited with $\mathrm{C}$ enhancement, summed together. As we will show, riparian sites that only fail on the soil $\mathrm{C}$ criterion were absent or rare in most of these 32 Iowa watersheds.

Assembling Watershed Data and Statistical Analysis. After classifying riparian catchments by SRB suitability, riparian catchment data were tabulated including the size of each riparian catchment and extent of tile drainage within each riparian catchment (including headwater catchments above stream initiation points). These results were aggregated by watershed to provide the proportion of riparian lengths suited to SRBs, and the extent of tile drainage in riparian catchments that drain to suitable SRB sites (proportion of watershed area). A one-way analysis of variance was conducted to determine if the MLRA-AHL landscape groupings significantly explained variation in the proportion of streambank suited to SRBs among watersheds. Data were log-transformed prior to analysis. If the ANOVA result was significant $(p<0.05)$, contrasts were planned to determine which differences in landscape designation were responsible for the signifi- cant ANOVA result. A regression was run to determine if the extent of SRB suitability in a watershed could predict the extent of tiledrained land that could benefit from SRB treatment. The SRB practice is not available for tile-drained lands found in headwater catchments because this drainage is discharged to a stream initiation point rather than through a streamside riparian zone. We compared the proportion of all tile drainage in each watershed to the proportion of tile drainage found in headwater catchments. Results indicate how much of the tile drainage in each watershed cannot be treated by an SRB without significantly modifying the practice and/or incorporating other treatment designs (e.g., denitrifying bioreactors, surface or subsurface flow wetlands).

\section{Results and Discussion}

Characterization of Watersheds and Riparian Catchments. The 32 watersheds (table 1) varied in size from about 4,200 to nearly 15,000 ha, based on summed areas of the riparian 
Table 1

Riparian catchment and saturated riparian buffer (SRB) suitability results for 32 watersheds.

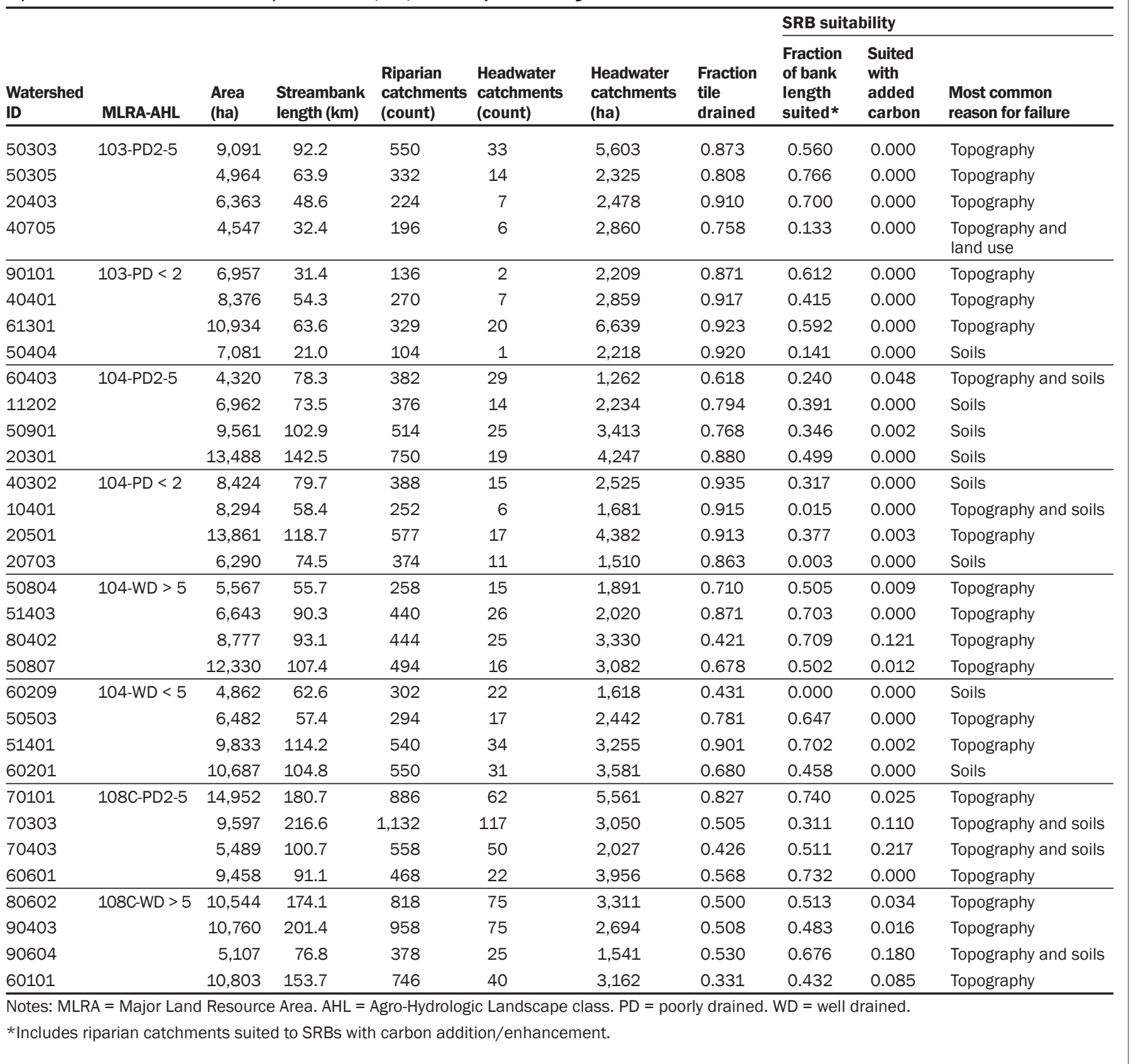

and headwater catchments. The combined length of streambanks in these watersheds varied by nearly an order of magnitude, from about 32 to $220 \mathrm{~km}$ (note $1 \mathrm{~km}$ of stream has $2 \mathrm{~km}$ of streambank). Stream order at the watershed outlets varied from first to fourth order, as one watershed in MLRA 103 only had one first-order stream reach, while one watershed in MLRA 108C had 117 first order reaches, with headwater catchments above each initiation point (table 1). The differences in stream order and streambank lengths also led to a wide number of riparian catchments among the 32 watersheds, from 104 to 1,132 .

The extent of tile drainage in each watershed was estimated from the area of agricultural fields that had $>90 \%$ cover of $<5 \%$ slopes, or, were $>40 \%$ covered by soil map units with dual soil hydrologic groups, e.g., B/D (Porter et al. 2018; Tomer et al. $2020 \mathrm{~b})$. This query provides an estimate of the likely maximum extent of tile-drained fields in each watershed. This extent of tile drainage varied from $92 \%$ in three watersheds found in MLRA 103 with a PD < 2 AHL class (i.e., dominated by low slopes and poorly drained soils), down to $33 \%$ in one watershed in MLRA $108 \mathrm{C}$ with a WD > 5 AHL class (i.e., dominated by sloping and well drained soils; table 1).

Statistical Results. The proportions of riparian lengths suited to SRB installation 
varied from $0 \%$ to $74 \%$ (table 1) among the 32 watersheds. Note the single zero value was reassigned to 0.001 for log-transformation and statistical analysis. The analysis of variance results showed landscape grouping did not explain significant variation in the proportion of streambanks deemed suitable for SRBs among watersheds $(p=0.23)$, nor in extent of tile-drained land above streambanks suited to SRBs $(p=0.16)$. This suggests regional landscape classifications provide little information for planners seeking to predict where SRBs can most contribute to $\mathrm{NO}_{3}-\mathrm{N}$ load reductions.

Installation of SRBs will typically be most beneficial where suitable riparian sites and tile-drained cropland are found in the same riparian catchments. We plotted the extent of riparian sites suited to SRBs (proportion of streambank length) against the extent of tiledrained land in riparian catchments above riparian sites suited to SRBs (proportion of watershed area). The resulting plot (figure 2) suggests extent of suitable SRB sites in a watershed is related $\left(R^{2}=0.73\right)$ to the extent of tile-drained lands that could be readily treated by those SRBs upon installation. However, as the extent of suitable sites increased by watershed, so did the apparent uncertainty around the estimated extent of treatable area (i.e., results appear heteroscedastic). The plot (figure 2) shows that in some watersheds it may be possible to treat tile drainage from $40 \%$ of the watershed using SRBs. More typically among these 32 watersheds, suitable SRB sites were indicated on $30 \%$ to $70 \%$ of streambanks, and areas of tile drainage above the suitable sites covered 15\% to $25 \%$ of the watersheds.

The most common reason that riparian sites failed the SRB suitability assessment is listed by watershed (table 1). Common reasons for failure included flat topography in MLRA 103 and steep topography in MLRA 108C; a mix of soils and topographic criteria limited site suitability among MLRA 104 watersheds. In three of four watersheds with $<15 \%$ of SRB-suited riparian lengths, soils criteria were the most common reason for failure.

Riparian lengths suited to SRBs with C enhancement, where SOC averaged $<1 \%$ to a $1 \mathrm{~m}$ depth, were only common in a few watersheds (table 1). That is, they were absent in 18 of the 32 watersheds, and comprised $<3 \%$ of riparian lengths in 7 others. However, in five watersheds, sites suggested for C

\section{Figure 2}

The proportion of streambank lengths suited for saturated buffer installation plotted against the estimated proportion of the watershed that could be treated by the saturated buffer practice; i.e., tile-drained areas within riparian catchments suited for saturated buffer installation. Plotted points each represent one watershed and are distinguished by Major Land Resource Area (MLRA).

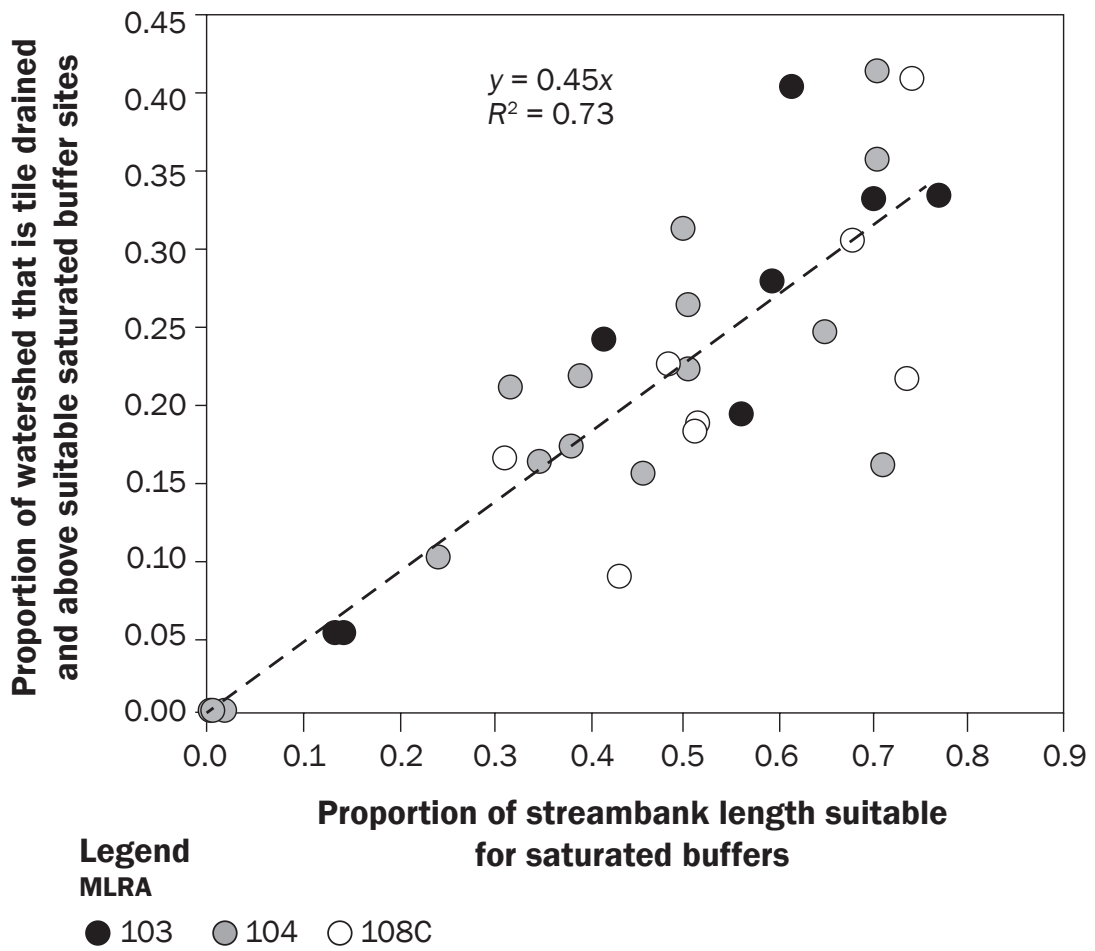

enhanced SRBs were found along $8 \%$ to $22 \%$ of riparian lengths. These five watersheds were found in MLRA 108C and/or had a WD > 5 AHL designation, i.e., in landscapes with well drained and/or sloping soils where tile drainage is least extensive (table 1). It may be appropriate to include high-biomass riparian species and/or denitrification walls (Schipper et al. 2010) in the SRB design where SOC stores are marginal. However, we note the USDA Natural Resources Conservation Service (NRCS) SRB practice standard has a more lenient SOC criterion than the ACPF tool, requiring only $0.75 \%$ SOC averaged to a $0.76 \mathrm{~m}$ depth (USDA NRCS 2018), rather than an average $1 \%$ SOC to a $1 \mathrm{~m}$ depth. The ACPF SRB siting tool was developed in 2016 for ACPFVersion 2, two years before the NRCS practice standard was released in 2018. The SRB tool was edited for ACPF version 3; subsurface texture (sand/gravel) and streambank height requirements were relaxed to improve the SRB tool's match with the NRCS practice standard. However, matching the $0.76 \mathrm{~m}$ SOC depth would require a rebuild of ACPF soils databases for over 11,000 watersheds. We emphasize that regardless of the SOC decision point, the $\mathrm{C}$ enhancement class of SRB suitability is meant to suggest design and management options to enhance performance, not site qualification or exclusion. Jaynes and Isenhart (2019) found evidence that soil drainage characteristics and presence of established buffer vegetation had the most influence on SRB performance for $\mathrm{NO}_{3}-\mathrm{N}$ removal.

The SRB practice cannot readily be applied to treat tile drainage from headwater catchments. The proportion of watershed areas that were tile drained and found in headwater catchments clearly varied among the three MLRAs (figure 3). Watersheds in MLRA 103 typically had $>30 \%$ of total land area that was tile drained and in headwater catchments, whereas MLRAs 104 and 108C typically had less than $30 \%$. Because these areas drain to stream initiation points rather than through riparian zones, this means the SRB practice would have to be substantially modified to provide denitrification services 


\section{Figure 3}

Plot showing the extents of tile-drained lands among 32 watersheds ( $x$-axis) plotted against the extents of tile-drained lands that are also within headwater catchments ( $y$-axis); these tiledrained lands do not drain through streamside riparian zones. Result indicates that saturated riparian buffers placed along streams are a more limited treatment option in Major Land Resource Area (MLRA) 103 than MLRAs 104 and 108C.

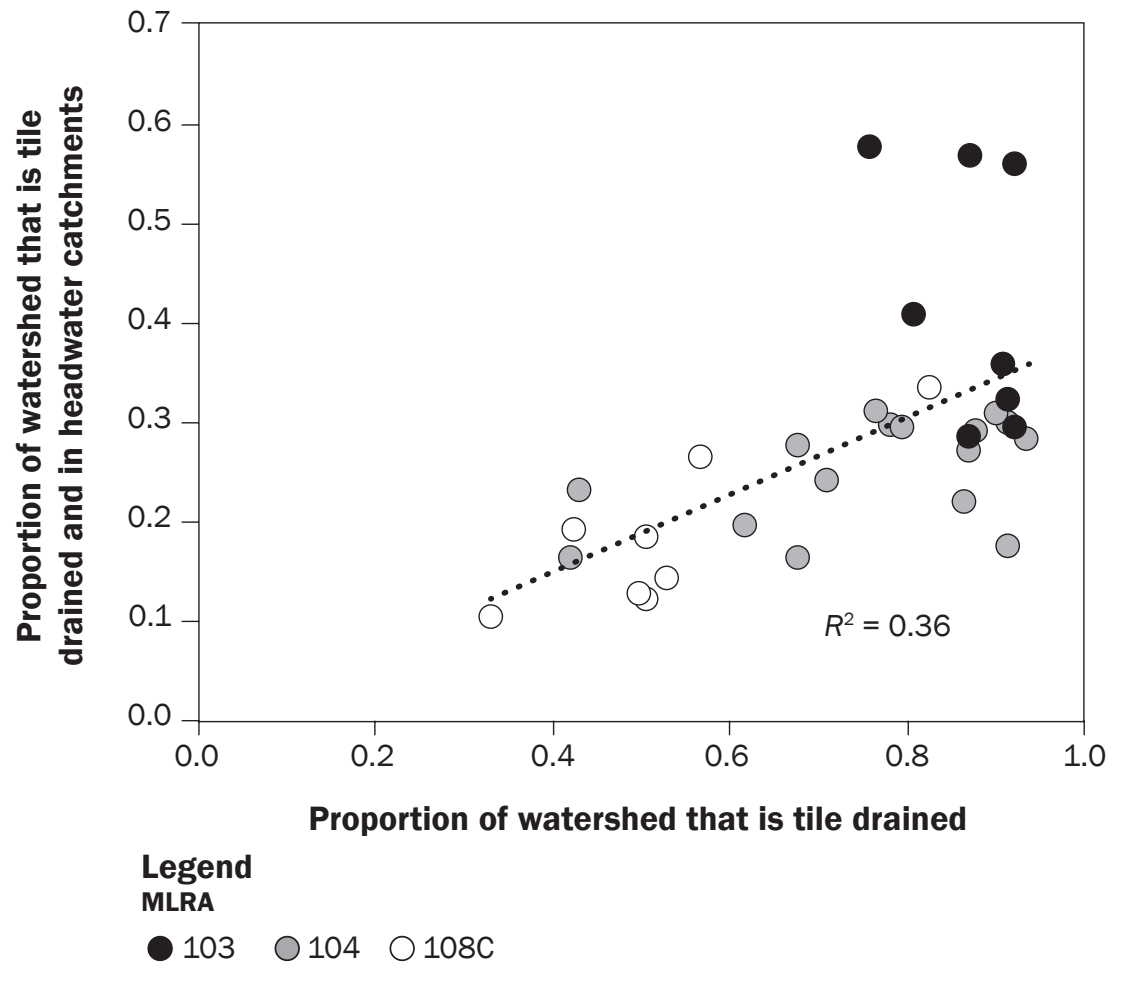

in headwater areas of MLRA 103. While other denitrification practices, i.e., bioreactors and/or nutrient removal wetlands, will be suited to many of these areas, there will also be a need to continue the creative thinking that led to the development, testing, and availability of the SRB practice, in order to provide a full suite of options to treat tile drainage from many headwater catchments in Iowa.

\section{Summary and Conclusions}

This multiwatershed assessment evaluated the extent of SRB-suited riparian sites among riparian catchments delineated for 32 watersheds representing landscape regions dominant in central and eastern Iowa. Sites suitable for SRBs designed to accept tile-drainage discharge into riparian soils for $\mathrm{NO}_{3}-\mathrm{N}$ reduction were common in most watersheds, but no discernible differences were found among regional landform classes. A small number of watersheds had few suitable SRB sites $(<20 \%$ of streambank length), but most had $>30 \%$ suitable sites into which tile drainage from $15 \%$ to $40 \%$ of the watersheds could be diverted. The design and management of SRBs in older, more incised, and steeper Iowa landscapes (i.e., watersheds in MLRA 108C and/or with a WD > 5 AHL designation) may need to consider options to increase $\mathrm{C}$ availability in riparian zone soils. Results indicate the SRB practice may have a substantial potential role for reducing $\mathrm{NO}_{3}-\mathrm{N}$ losses for many tile-drained midwestern watersheds. However, tile-drained areas that are in headwater catchments, particularly in MLRA 103, cover a substantial area and will require alternative treatment designs, including but not limited to wetlands, bioreactors, and novel practices suited for implementation near points of stream initiation.

\section{Disclaimer}

Mention of trade names or commercial products in this publication is solely for the purpose of providing specific information and does not imply recommendation or endorsement by the US Department of Agriculture (USDA).

\section{Acknowledgements}

Development of the Agricultural Conservation Planning Framework was supported by a USDA interagency agreement between the Agricultural Research Service and the Natural Resources Conservation Service. USDA is an equal opportunity provider and employer.

\section{References}

Amado, A.A., K.E. Schilling, C.S. Jones, N. Thomas, and L.J. Weber. 2017. Estimation of tile drainage contribution to streamflow and nutrient loads at the watershed scale based on continuously monitored data. Environmental Monitoring and Assessment 189:426, https://doi. org/10.1007/s10661-017-6139-4.

Carlisle, D.M., J. Falcone, D.M. Wolock, M.R. Meador, and R.H. Norris. 2010. Predicting the natural flow regime: Models for assessing hydrologic alteration in streams. River Research and Applications 26:118-136.

Christianson, L., J. Tyndall, and M. Helmers. 2013. Financial comparison of seven nitrate reduction strategies for Midwestern agricultural drainage. Water Resources and Economics 2-3:30-56.

Dosskey, M.G., P. Vidon, N.P. Gurwick, C.J. Allen, T.P. Duval, and R. Lowrance. 2010. The role of riparian vegetation in protecting and improving chemical quality in streams. Journal American Water Resources Association 46(2):261-277.

Groh, T.A., L.E. Gentry, and M.B. David. 2015. Nitrogen removal and greenhouse gas emissions from constructed wetlands receiving tile drainage water. Journal of Environmental Quality 44(3):1001-1010

Hefting, M.M., R.N. van den Heuvel, and J.T.A. Verhoeven. 2013. Wetlands in agricultural landscapes for nitrogen attenuation and biodiversity enhancement: Opportunities and limitations. Ecological Engineering 56:5-13.

Hoover, N.L., A. Bhandari, M.L. Soupir, and T.B. Moorman. 2015. Woodchip denitrification bioreactors: Impacts of temperature and hydraulic retention time on nitrate removal. Journal of Environmental Quality 45(3):803-812

Jaynes, D.B., and T.M. Isenhart. 2014. Reconnecting tile drainage to riparian buffer hydrology for enhanced nitrate removal. Journal of Environmental Quality 43(2):631-638

Jaynes, D.B., and T.M. Isenhart. 2019. Performance of saturated riparian buffers in Iowa, USA. Journal of Environmental Quality 48(1):289-296.

Kovacic, D.A., M.B. David, L.E. Gentry, K.M. Starks, and R.A. Cooke. 2000. Effectiveness of constructed wetlands in reducing nitrogen and phosphorus export from agricultural tile drainage. Journal of Environmental Quality 29(4):1262-1274.

Lenhart, C., B. Gordon, J. Gamble, D. Current, N. Ross, L. Herring, J. Nieber, and H. Peterson. 2016. Design and hydrologic performance of a tile drainage treatment wetland in Minnesota, USA. Water 8(12):549. 
Liu, X., X. Zhang, and M. Zhang. 2008. Major factors influencing the efficacy of vegetated buffers on sediment trapping:A review and analysis. Journal of Environmental Quality 37(5):1667-1674.

Mayer, P.M., S.K. Reynolds, M.D. McCutchen, and T.J. Canfield. 2007. Meta-analysis of nitrogen removal in riparian buffers. Journal of Environmental Quality 36(4):1172-1180

Moorman, T.B., M.D. Tomer, D.R. Smith, and D.B. Jaynes. 2015. Evaluating the potential role of denitrifying woodchip bioreactors in reducing watershed-scale nitrate loads: A case study comparing three Midwestern (USA) watersheds. Ecological Engineering 75:441-448.

Norton, E.A. 1937. Provisional problem areas in soil conservation research in the United States. Soil Science Society of America Proceedings 1:495-504.

Olmernik, J.M., and G.E. Griffith. 2014. Ecoregions of the conterminous United States: Evolution of a hierarchical spatial framework. Environmental Management 54:1249-1266.

Porter, S.A., M.D. Tomer, D.E. James, and J.D. Van Horn. 2018. Agricultural Conservation Planning Framework ArcGIS Toolbox User's Manual, Ver. 3. Ames, IA USDA Agricultural Research Service National Laboratory for Agriculture and the Environment. www. acpf4watersheds.org.

Schilling, K.E., C.F. Wolter, and E. McLellan. 2015. AgroHydrologic Landscapes in the Upper Mississippi and Ohio River basins. Environmental Management 55:646-656.

Schipper, L.A., W.D. Robertson, A.J. Gold, D.B. Jaynes, and S.C. Cameron. 2010. Denitrifying bioreactors-An approach for reducing nitrate loads to receiving waters. Ecological Engineering 36(11):1532-1543.

Simon, A., and M. Rinaldi. 2006. Disturbance, stream incision, and channel evolution: The roles of excess transport capacity and boundary materials in controlling channel response. Geomorphology 79:361-383.

Tomer, M.D., W.G. Crumpton, R.L. Bingner, J.A. Kostel, and D.E. James. 2013a. Estimating nitrate load reductions from placing constructed wetlands in a HUC-12 watershed using LiDAR data. Ecological Engineering 56:69-78.

Tomer, M.D., D.E. James, and C.M.J. Sandoval-Green. 2017. Agricultural Conservation Planning Framework: 3. Land use and field boundary database development and structure. Journal of Environmental Quality 46(3):676-686.

Tomer, M.D., S.A. Porter, D.E. James, K.M.B. Boomer, J.A. Kostel, and E. McLellan. 2013b. Combining precision conservation technologies into a flexible framework to facilitate agricultural watershed planning. Journal of Soil and Water Conservation 68(5):113A-120A, doi:10.2489/jswc.68.5.113A.

Tomer, M.D., S.A. Porter, D.E. James, and J.D. Van Horn. 2020a. Riparian catchments: A landscape approach to link uplands with riparian zones for agricultural and ecosystem conservation. Journal of Soil and Water Conservation, doi:10.2489/jswc.2020.1220A.

Tomer, M.D., J.D. Van Horn, S.A. Porter, D.E. James, and J. Niemi. 2020b. Comparing Agricultural Conservation Planning Framework (ACPF) practice placements for runoff mitigation and controlled drainage among 32 watersheds representing Iowa landscapes. Journal of Soil and Water Conservation, doi:10.2489/jswc.2020.00001.

University of Northern Iowa. 2016. Iowa LiDAR Mapping Project. Cedar Falls, IA: University of Northern Iowa. http://www.geotree.uni.edu/lidar/.

USDA NRCS (Natural Resources Conservation Service). 2006. Land Resource Regions and Major Land Resource Areas of the United States, the Caribbean, and the Pacific Basin. USDA Handbook 296. Washington, DC: USDA Natural Resources Conservation Service.

USDA NRCS. 2018. Conservation Practice Standard, Saturated Buffer, Code 604. USDA-NRCS Field Office Technical Guide. Bismarck, ND: USDA Natural Resources Conservation Service, North Dakota Office. https://efotg.sc.egov.usda.gov/references/public/ND/ ND_604_Standard.pdf. 